\title{
Total Synthesis of BE-43472B
}<smiles>CCO[C@H]1C(C)Cc2onc3c2C1(OC)C(=O)c1cccc(OC)c1-3</smiles>

J. Am. Chem. Soc. 2003, 125, 8432<smiles>COc1cc(Cl)c(OC)c2c(OC)c(Br)ccc12</smiles>

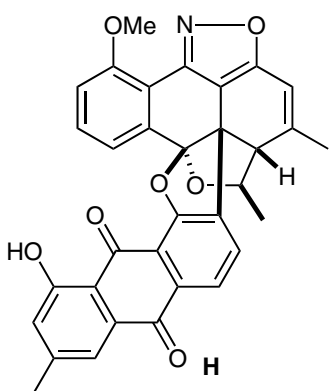<smiles>C=C(C)C=C(OC)OC</smiles>

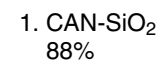<smiles>[13CH]S(=O)(=O)O</smiles>
$\mathrm{K}_{2} \mathrm{CO}_{3}, \mathrm{MeOH}$ 94\%

Diels-Alder cycloaddition<smiles>CCO[C@H]1[C@@H](c2ccc3c(OC)cc(Cl)c(OC)c3c2OC)Cc2onc3c2[C@@]1(O)c1cccc(OC)c1-3</smiles><smiles>CCO[C@H]1C(C)Cc2onc3c2C1(Cc1ccc2c(OC)cc(Cl)c(OC)c2c1OC)C(=O)c1cccc(OC)c1-3</smiles><smiles>COc1cccc2c1-c1noc3c1C1(O3)c3c(ccc4c(OC)cc(Cl)c(OC)c34)CC1C(C)C(C)=C2</smiles>

$\mathbf{F}$
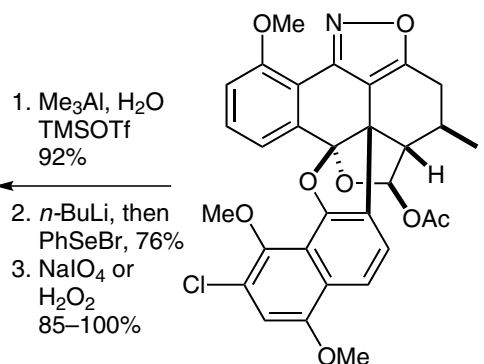

\section{Category}

Synthesis of Natural

Products and

Potential Drugs

\section{Key words}

antibiotics

anthraquinone natural products

pinacol rearrangement

Diels-Alder cycloaddition
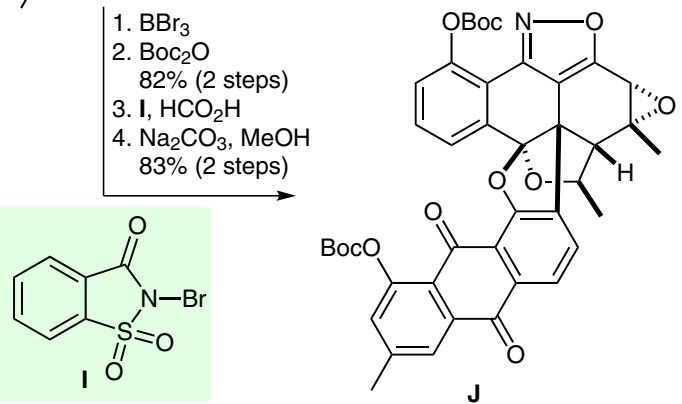

Significance: The aromatic polyketide BE-43472B was isolated from a marine Streptomyces species and was shown to exhibit significant activity against several drug-resistant bacterial strains. Moreover, its unprecedented structure includes two anthraquinones linked through a highly hindered carbon-carbon bond as well as five contiguous stereocenters. The strategy reported by Suzuki and co-workers relies on a highly efficient pinacol rearrangement to form the key $\mathrm{C}-\mathrm{C}$ bond between the two anthraquinone monomers.
Comment: The synthesis starts with lithiation of bromonaphthalene $\mathbf{B}$, followed by addition to ketone $\mathbf{A}$. The resulting tertiary alcohol $\mathbf{C}$ was treated with triflic acid to induce a pinacol rearrangement to produce ketone $\mathbf{D}$. Construction of the tetrahydrofuran ring proceeded via acetal E followed by methylation using $\mathrm{Me}_{3} \mathrm{Al}$. Oxidation of $\mathbf{F}$ and subsequent quinone Diels-Alder reaction with diene $\mathbf{G}$ delivered anthraquinone $\mathbf{H}$. This intermediate was converted into the natural product $( \pm)$-BE-43472B via epoxide $\mathbf{J}$.

SYNFACTS Contributors: Erick M. Carreira, Stefan Diethelm

Synfacts 2013, 9(8), 0807 Published online: 18.07.2013

Dol: 10.1055/s-0033-1339371; Reg-No.: C04013SF 